\title{
Scope and Limitations of Municipal Health Councils: A Case Study
}

\author{
Carla A. A. Ventura, Mauro Serapioni, Marcela J. Miwa (iD, \\ and Márjore S. Jorge
}

\begin{abstract}
This case study analyzed citizen participation at the Municipal Health Council (MHC) of Ribeirão Preto, in the state of São Paulo (Brazil), using a qualitative approach with a phenomenological basis and methodological triangulation: (i) analysis of the minutes of the meetings, (ii) passive observation, and (iii) semi-structured interviews with councillors. The interviews were analyzed using content analysis and categorized according to three themes: (i) challenges and limitations of participation in the MHC, (ii) representativeness of the councillors, (iii) the Council and its influence on local health-care policies. Problems with infrastructure and the organizational logistics of the MHC, as well as relational difficulties among members occupying varied roles and having different levels of knowledge about health, influenced the quality of the deliberative process. In contrast to studies that indicate poor participation by health-care service users in spaces of dialogue around health-care policies, this study found the users actively engaged and committed.
\end{abstract}

KEY WORDS: citizen participation, health councils, Brazil

\section{Introduction}

Internationally, citizen participation has been increasingly on the agenda in discussions on the process of health-care reforms. In recent years, the demand for greater participation of civil society has increased, and political and social scientists have taken a growing interest in analyzing the social practice of participation that leads to active citizenship and high-intensity democracy (Santos, 2002).

Arguments in favor of citizen participation in health-care decision-making processes include: (i) the experiential knowledge of health-care service users improves the quality of decisions (Barnes et al., 2008; Rojatz \& Forster, 2017); (ii) public health care is most effective when decisions are shared with those affected (Scutchfield, Hall \& Ireson, 2006); (iii) community health needs must be aligned with health-care services (Abelson et al., 2003); (iv) the users' perspectives should be valued in the decision-making process (Charles \& De Maio, 1993); (v) the 
participation of users and citizens increases the legitimacy and accountability of health-care services (Tritter \& McCallum, 2006); (vi) the voice of users is an important strategy in overcoming the growing "democratic deficit" nature of health-care systems, particularly after the managerial reforms of the 1990s (Cooper, 1995).

However, the question of how participation in health-care systems should be designed and implemented remains. Experience in this field shows that, despite good intentions and efforts, results have been modest (Abelson et al., 2003; Conklin, Morris, and Nolte, 2015; Li, Abelson, Giacomini, \& Contandriopoulos, 2015). In recent years, deliberative methods have been considered by policymakers as an innovative strategy to improve interaction between decision makers and service users. Deliberative democracy aims to foster decision-making processes by promoting discussions and analyses-preferably in small groupsin which participants can freely express different points of view in a democratic environment (Dryzek, 2009). Deliberation is considered an important aspect of democracy, and occurs when discussion, explanation, and justification replace consensus and voting as conceptual cores of legitimacy (Grönlund, Bächtiger, \& Setälä, 2014).

The benefits of deliberative processes include: greater citizen participation in health-care policies, the potential to change participants' opinions, the ability to increase tolerance and understanding between groups holding different points of view, and being a qualified means of reaching collective decisions (Mitton, Smith, Peacock, Evoy, \& Abelson, 2009). Lehoux, Daudelin, Demers-Payette, and Boivin (2009) recommend adopting deliberative processes because of their potential to maximize mutual learning both within expert groups and between experts and lay people.

The deliberative approach has gained increasing ground in health-care systems in several countries that understand the need to create participatory forums and spaces that encourage dialogue between different actors of the healthcare system.

However, it is also important to mention some critical aspects of deliberative exercises identified in the literature, such as the problem of representativeness (Bispo Júnior \& Gerschman, 2015), the potential for influence (Conklin et al., 2015) and the unavoidable power imbalance between the sponsor of the deliberative process and the participants (Gooberman-Hill, Horwood, \& Calnan, 2008).

The Citizens' Jury is one of the most widely used deliberative methods in the British health-care system (Parkin \& Paul, 2011). In Canada, dialogue sessions (Choice Work Dialogue) with representatives of the public have been adopted to learn about the views of the Canadian population on health-care policies (Maxwell, Rosell, \& Forest, 2003). In the Netherlands, Health Councils and Client Councils include user organizations in decision making on policies and on the organization of health-care services (Bovenkamp, Trappenburg, \& Grit, 2009). In Italy, the Emilia-Romagna Region has set up Mixed Advisory Committees (Comitati Consultivi Misti), with representatives from user associations, health-care 
professionals, and managers, aiming to guarantee and defend the rights of all the parties (Serapioni \& Duxbury, 2012).

In Brazil, the Municipal Health Councils (MHC) were implemented after the creation of the Unified Health System (SUS), as a collegiate body composed of representatives of service users (50 percent), health workers ( 25 percent), and health managers and outsourced service providers (25 percent). The MHCs formulate municipal health policies and are also responsible for approving accounts, budgets, and health plans, an indispensable requirement for the transfer of federal funding to state and municipal governments (Cornwall \& Shankland, 2008). Within the SUS's principles of equity and universal and integral care, the MHCs were implemented in order to foster a culture of citizen participation within the health system.

This extensive power of spending oversight explains the definition of controle social (literally social control) given to the MHCs, and their designation as deliberative, rather than consultative, emphasizing, in this way, direct participation in decision-making processes (Rolim, Cruz, \& Sampaio, 2013). The ideals embodied in the concept of controle social were established in the law, which created the Single Health System in the country, and the expectation was that this participation would contribute to the empowerment of civil society (Cornwall, 2007).

According to Cornwall (2007), the spread of participatory spaces in the Brazilian health system is reconfiguring representation at the community level, and this process holds the potential to reinvigorate politics with new faces and new practices. In fact, between 1990 and 2000, more than 5,000 Health Councils were established in Brazil, and approximately 100,000 citizens participated annually in their activities, engaging in policymaking through a mechanism that promoted greater transparency and accountability. These advances in the health sector, along with the practice of participatory budgeting, have resulted in Brazil being recognized, over the last decade, as an important hub of democratic innovation in the world (Cornwall \& Shankland, 2008).

Despite the progress made in the last 25 years by the MHCs in the design, implementation, and evaluation of health-care policies, there is still a long way to go for the participation of the councillors to be effective in the rollout of public health-care policy. From this basis, the present study aims at analyzing social participation in the MHC of Ribeirão Preto, in the state of São Paulo, in order to have a deeper comprehension of some critical aspect of public participation highlighted by other national and international research studies, such as: the strength and weaknesses of the MHC as a deliberative space, the question of representativeness of this forum, and its potential for influencing the health decision-making process.

\section{Methods}

Qualitative analysis was adopted to investigate social participation in the MHC and to understand the social phenomena from the points of view of the 
main actors. This approach facilitated understanding of how reality is viewed by the various role-players: representatives of the users, health-care professionals, and managers. From this starting point, we carried out a qualitative case study (Yin, 1994), using several resources and techniques to collect, process, and analyze data. The study applied methodological triangulation (Patton, 1999), which allowed for various aspects of participation in the MHC to be described. Field research utilized the following data collection techniques: (i) analysis of documents and MHC meeting minutes, (ii) direct observation, and (iii) semi-structured interviews with councillors.

\section{Analysis of Documents and Meeting Minutes}

Document analysis proved to be an essential tool to elicit the studied social phenomena (Quivy \& van Campenhoudt, 1998). A variety of documents, prepared by the institutions involved in the study, were analyzed, such as legislation on the health system and the MHCs, as well as federal, state, and municipal policies. The minutes of the MHC meetings held between 2009 and 2012 (the tenure of MHC members) were also analyzed. The first step was a thorough reading of the minutes to obtain data on the number of meetings held, the number of meetings with a quorum, attendance of members, and the key issues raised by the users, bearing in mind that the primary focus of analysis in this study is user participation. These results were then analyzed together with the interviews and observations.

\section{Direct Observation}

Direct observation in 18 council meetings over the course of 2009-2012 were carried out. Direct observation was used to gather information about the quality of participation in the $\mathrm{MHC}$, and to note how participation and communication between the members of the MHC occurs. Participants' comments, the agenda and dynamics of the discussion, participation of the members, and level of consensus or conflict between the different actors was recorded. This allowed gathering the greatest amount of information on the dynamics of the Council and the performance of the councillors to be obtained. The content of the observations was included in the results, enriching the data obtained from the other sources.

\section{Semi-Structured Interviews}

Semi-structured exploratory interviews were conducted with incumbent MHC members. To reflect the ratio between the sectors of participants, interviews were held with the following representatives: two managers, three health-care professionals, and five users. The semi-structured interviews aimed at deepening understanding of the issues related to $\mathrm{MHC}^{\prime}$ s representativeness, its influence on decision makers, as well as obtaining opinions about the potentialities and limits of the MHC. The interviews were recorded digitally, transcribed, and analyzed 
according to thematic content. After systematizing the data, an analysis of meanings was undertaken, in which contents were identified that converged toward similar meanings, and were then grouped by themes. Content of the interviews was analyzed by all authors. At first, all authors read and reread the content of the interviews. Following, each researcher, separately, explored and organized the data in themes. After this first coding, researchers compared results that were independently derived, crosschecked codes, and refined the themes repeatedly until they had a consensus on the final themes. Finally, they treated and interpreted the data. In order to protect the anonymity of the participants, their quotes are indicated in the manuscripts as G (managers), P (professionals), and U (users), followed by numbers indicating the order of their interviews.

This study was approved by the Research Ethics Committee of the Ribeirão Preto College of Nursing of the University of São Paulo (Protocol no. 1450/2011), and the goal of the study was explained to all participants, who agreed to participate and then signed an Informed Consent form.

\section{Results and Discussion}

The MHC: Structure and Dynamics of the Meetings

The establishment of the MHC was approved at the second Municipal Health Conference in April 1991. The MHC consists of 26 members and their respective substitutes. The members represent the following sectors: 4 from municipal offices (2 from health, 1 from social welfare, and 1 from finance); 1 from the Superintendent of the Control of Endemic Diseases (Sucen); 1 from FMRP-USP's Hospital das Clinicas; 1 representative from the School of Public Health, Ribeirão Preto Campus, of the University of São Paulo; 1 representative of private education in health care, 1 representative of philanthropic organizations, charities or non-profit hospitals and health services; 1 representative of private associations and companies; 1 representative of the Medical Center of Ribeirão Preto; 5 union representatives; 2 representatives of Organizations of Pathology Carriers; 4 neighborhood associations, and 3 local health councils. Of these 26 members, there were 18 men and 6 women, indicating a level of inequality in gender representation. However, among the substitutes, there was equal gender representation, with 13 men and 13 women. The MHC holds monthly meetings (usually on Thursdays) which are open to the public; and the date, time, and venue are made available on the City Hall website.

The observations showed that the meetings follow a standard structure and are initiated by the chairperson, followed by presentations; items on the agenda for discussion; and, finally, the remarks by the councillors. After the presentation, the Chairperson of the Council opens the discussion to the representatives of the various sectors. Questions are usually answered by the managers or guests who presented the topic of discussion. When the matter requires deliberation, after all the contributions have been made, the manager puts to a vote the approval of the topic or proposals suggested by the councillors. 
Users expressed their opinions freely, although sometimes they repeated comments that had already been made. During the meetings, it was evident that there was a lack of preparation and prior study of items on the agenda. This is a topic that has been identified in previous studies and which highlights the lack of a policy for the qualification of councillors across the segments, and reveals a lack of concern of the local managers in improving the participatory process (Bezerra, 2009).

These difficulties limit the effectiveness of the MHC, because one of the fundamental characteristics of deliberative democracy is the process of dialogue based on argumentative interaction, in which the participants state their reasons and defend their positions (Vieira \& Silva, 2013). However, for dialogue or the deliberative process to take place, it is necessary for the parties involved to have sufficient knowledge and information on the topic, so that they can present an informed opinion. In this regard, having participants informed on the subject under discussion is an essential prerequisite of deliberative approaches.

The literature confirms the tendency that, in relation to the other participants, users are more likely to have lower education and not much knowledge on health care, which tends to hinder their active participation. Many studies in the literature report poor user participation (Cotta et al., 2011; Duarte \& Machado, 2012). However, in the present study, users were highly engaged in the meetings and freely expressed their opinions, as can be observed in the analysis of the minutes.

\section{MHC Meeting Minutes From 2009 to 2012}

The analysis of the meeting minutes from 2009 to 2012 is summarized in Table 1. Table 1 lists the total number of meetings and the number of meetings with a quorum, that is, the minimum mandatory number of members present or formally represented.

Table 1 shows that there were good quorum rates at the MHC meetings. In each of the years, more than 75 percent of meetings had a quorum. Although the minutes and observations note that there was a lack of a quorum at the beginning or at the end of the meetings, in general there were enough participants to proceed with the MHC meetings.

Table 2 describes attendance per sector. In terms of attendance at the MHC meetings within the period of study, there was less participation by health-care professionals. A councillor linked to health-care education presented two possible

Table 1. Meetings Held by the MHC and the Respective Quorum, From 2009 to 2012

\begin{tabular}{lcc}
\hline Year & Total Number of Meetings & Number of Meetings With a Quorum (\%) \\
\hline 2009 & 12 & $11(90.9)$ \\
2010 & 14 & $11(78.57)$ \\
2011 & 18 & $14(77.77)$ \\
2012 & 17 & $13(76.47)$ \\
\hline
\end{tabular}


Table 2. Frequency (\%) of Attendance Per Sector of MHC Members in the Monthly Meetings From 2009 to 2012

\begin{tabular}{lccc}
\hline Sector Year & Managers (\%) & Workers (\%) & Users (\%) \\
\hline 2009 & 60 & 72.91 & 73.07 \\
2010 & 82.14 & 58.92 & 66.48 \\
2011 & 84.72 & 55.55 & 63.24 \\
2012 & 60.29 & 44.53 & 69.68 \\
Average & 71.78 & 57.97 & 68.11 \\
\hline
\end{tabular}

reasons for the low participation of health-care professionals in the MHC meetings: a limited understanding of the health-care system, and the fact that sometimes health-care professionals only have an interest in their own field. When the participant has nothing to do with their profession, they tend to not get involved:

so when he doesn't have a good idea of what is going on, he will often go to the safety of his field ... so the representation of the workers ... I think she is more shy, less visible because she does not have a broad understanding of health policies, it goes something like this: if I am a doctor, I will speak up about the things that have to do with medicine, nursing ...

\section{Issues Raised by Users at MHC Meetings}

In the minutes, the members of the Council had the opportunity to express themselves, ask questions, and comment on the items on the agenda. Most of the managers' comments were made to clarify topics, provide information, steer the meetings, and manage voting on proposals put forward. Workers primarily proposed solutions to issues raised, and commented on their professional practice and the structure of health-care services.

The users asked more questions and made the most suggestions, raising discussions about their needs and challenging the "established order" of the Council. In relation to this point, the attitude of some councilors, who left the meeting arguing that the steering procedure was irregular, is noteworthy.

Users complained about situations in which they felt disrespected by other councillors, for example, when public money was given to the Pró-Santa Casa Program without first being discussed at the MHC, and when the regulations of the 2nd Municipal STD/AIDS Conference were not presented in advance. User representatives raised many issues at the MHC from their first-hand experiences related to health-care services, such as the lack of doctors and beds, and the need for renovations or expansions in units. The users' contribution is important, because the points they raised affect the communities of which they are a part and which directly influence their own access to health care. 
It is important to note that users' representatives showed dissatisfaction with the lack of a designated work area. After many requests had been submitted, one room with two tables and a computer was given for the councillors to use. Another factor that hinders participation, mentioned by the users' representatives, was the lack of contribution toward transportation costs. There is a fragile infrastructure for maintaining social participation, represented by users' representatives, while such infrastructure is generally made available to other sectors inside the MHC. This is an issue addressed in the national literature. Table 3 identifies the participation of user representatives and presents the key issues they raised during the 4 years of MHC meetings.

Thus, the key role of user representatives stands out, considering both the frequency of their participation in MHC meetings (Table 2) and their contributions at meetings over the 4 years (Table 3). This result is interesting, as it differs from the results of other national studies (Cotta et al., 2011; Cristo, 2012; Duarte \& Machado, 2012).

\section{Councillors' Experience With the MHC}

Exploratory interviews were conducted with 10 out of 26 councillors who were on the council from 2009 to 2012: 2 representatives of managers, 3 representatives of service providers, and 5 of the users, respectively identified as G, P and U. ${ }^{1}$ Most of the participants were male, married, and had been in the council for an average of 5 years) and, therefore, they had considerable experience as councillors). In the next section, the results will be presented and discussed according to three categories: (i) challenges and limitations of participation in the $\mathrm{MHC}$, (ii) representativeness of the councillors, (iii) the Council and its influence on local health-care policies.

\section{Challenges and Limitations of Participation in the MHC}

According to the participants, the public is largely unaware of the possibilities and opportunities of participating in the MHC due to a lack of information.

The existence, purpose, objectives of the Councils could and should be made clearer to the public. (G1)

Some participants also mentioned that some users prefer to air their criticisms of the health-care services in the local media, rather than making the most of the opportunities for participation.

Even when they have some problems, they do not come. They prefer to call the press or go on television rather than come and participate and make suggestions. (G2)

Studies carried out nationally have also revealed a deficit in the general public's knowledge about what the MHC does and how they can participate in 
Table 3. Key Issues Raised by the Users Between the Years of 2009 and 2012

\begin{tabular}{|c|c|}
\hline & Issues \\
\hline $\begin{array}{l}\text { Issues concerning the organization of the } \\
\text { MHC }\end{array}$ & $\begin{array}{l}\text { - Questions about the substitution of incumbent councillors by } \\
\text { others who are not their alternates, without election. } \\
\text { - Inquiries about transportation vouchers and parking tickets for } \\
\text { councillors attending meetings. } \\
\text { - Criticism of managers who do not stay until the end of the } \\
\text { meetings. } \\
\text { - Comment about the absence of representatives of the Municipal } \\
\text { Health Department at meetings. } \\
\text { - Request for the participation of the Regional Health Directorate } \\
\text { (DRS) in the MHC, since it is not possible to discuss beds and } \\
\text { regional regulation without DRS participation. } \\
\text { - Proposal for the establishment of a Budget Control Committee. } \\
\text { - Call for the establishment of an organizing committee of the Local } \\
\text { Health Councils. } \\
\text { - Requests for the Center for Psychosocial Care-Alcohol \& Drugs } \\
\text { (CAPS-ad II) to submit quarterly statements to the MHC on the } \\
\text { services performed in comparison with the objectives that were } \\
\text { set. } \\
\text { - MHC needs to be better informed on the sources of funding for } \\
\text { the health-care services of Ribeirão Preto and its investments }\end{array}$ \\
\hline $\begin{array}{l}\text { Issues relating to the provision of health- } \\
\text { care services in the region }\end{array}$ & $\begin{array}{l}\text { - Request for an Emergency Care Unit (UPA) for a remote } \\
\text { neighborhood. } \\
\text { - Request for Mental Health Service to provide management } \\
\text { support to the } 16 \text { ESF (Family Health Strategy). } \\
\text { - Requests for the substitution of the manager of one of the Basic } \\
\text { Health Unit (UBDS) who is never present in the Unit. } \\
\text { - Suggestion to invite managers of the Healthcare Units so that they } \\
\text { can clarify and discuss issues. } \\
\text { - Request for a gynecologist at one of the Basic Healthcare Unit } \\
\text { (UBS), as promised by the president of the MHC, and who has so } \\
\text { far not been assigned. } \\
\text { - Requests for the Commission to analyze the flow of emergency } \\
\text { admissions. } \\
\text { - Suggestion that nebulization is done in the streets due to the } \\
\text { increase of dengue. } \\
\text { - Comments about complaints received in CAPS-Alcohol and } \\
\text { Drugs on therapeutic communities and requests that this be } \\
\text { discussed in the Council. } \\
\text { - Concern about the lack of doctors in the Units. } \\
\text { - Worsening of Mobile Urgency Care Unit (SAMU) and delay in its } \\
\text { regulation. } \\
\text { - Requests that the "Leva e Traz da Saúde" non-emergent } \\
\text { healthcare transport service operates until 10pm. } \\
\text { - Hospitals \& Clinics (HC) Ombudsman does not work. } \\
\text { - Complaint about medical care at a Basic Healthcare Unit (UBS). } \\
\text { - Discontent regarding the location of care for users of a } \\
\text { Physiotherapy Center. }\end{array}$ \\
\hline
\end{tabular}

their activities (Escorel \& Moreira, 2009). In relation to this point, it is necessary to note that some of the participants believe it is important for the MHC to publish their achievements in the media, so that the public knows how the Council works and what it is doing to improve health-care services. Several studies confirm this idea and suggest that greater dissemination of information about the activities carried out by MHC would strengthen social control. 
On the other hand, participants highlighted problem areas in the performance of the councillors and emphasized the need to develop training courses. The small number of councillors who receive training before joining the Council reveals a weakness of the Council. This may be a consequence of the paucity of training on subjects related to social control, or a kind of "side effect" of the rotation that the law enforces for councillors. National research studies indicate that capacity building is imperative to achieve effective participation (Silva \& Pelicioni, 2013).

In this respect, the need for the MHCs to become autonomous in formulating their own processes of training is evident. This autonomy would allow the MHC to define the information that is required for enabling councillors to play their roles, avoiding what is commonly seen: the design of projects and training programs for councillors, which do not contemplate councillors' needs. The experience in training programs for councillors shows the tendency to replace "education for citizenship" with training of a technical content, carried out by paid employees, which limits political representation and the promotion of citizenship (Escorel \& Moreira, 2009).

Furthermore, pedagogical methodologies and approaches often do not address the diversity and heterogeneity of groups. Therefore, it is challenging to design approaches that can meet these needs and socialize "technical" knowledge, so that it can be "assimilated" by heterogeneous groups, as is the case of the councillors, as described by Alencar (2012) in her study of the MHC of Porto Alegre. According to the councillors who participated in the present study, the lack of knowledge is predominantly due to the lack of effective sources of information about rights. Through this process, the value of movements for education on rights is recognized as an essential step for the empowerment of users (Ventura, Mello, Andrade, \& Mendes, 2012). To this end, the MHC, through its representatives, could play a more active role with the sectors in training and educating the public about their rights.

On the one hand, health-care professionals generally do not value the space for dialogue as an opportunity to learn from public knowledge and to see other perspectives of health care (Soratto \& Witt, 2013), which is contrary to the results of international surveys that recommend the incorporation of users' knowledge and experience in the processes of decision making (Callon, Lascoumes, \& Barthe, 2001; Rojatz \& Forster, 2017). On the other hand, a significant sector of the population uses the public participation space as a "complaints counter" about health care (Cruz et al., 2012). Therefore, it is important to develop a model of participation with legitimacy in the relationship between representatives and their support base, particularly among councillors, users, and the community.

\section{Representativeness of the Councillors}

For social control over the health system to be effective, the dissemination and circulation of information among representatives of collegiate bodies and the people they are representing is essential, especially as this communication occurs 
through a complex web of informal relationships (Batista \& Melo, 2011). Participants reported individualistic participation, as the representatives do not meet with the community to bring their demands together. In other words, there is no effective channel of communication between the representatives and the public:

Generally, I don't see representatives working with their sectors to put forward a proposal (...). (P2)

I think the recommendations would have to be written in the neighborhoods and then taken from there to the council. (U5)

Each councillor represents a sector of society and should be on the council to raise the needs and suggestions from their community to improve the health-care system. It is important to remember that councillors, therefore, should closely monitor the health of the population and the quality of services offered (Brasil, 2010). When visiting health-care facilities, they need to listen to users and employees, so that they can bring their concerns to a MHC meeting (Brasil, 2010). However, as described by other national studies (Bispo Júnior \& Gerschman, 2015), health-care representatives and the communities they represent are not connected. There is a distinct lack of effective communication between the MHC members and the public, which increases the risk that the community "will not know what their representative does on the council" (Labra, 2009). Therefore, a decisive step is for the council member to regularly pass information concerning discussions held by the Council to the people they represent. This will encourage public participation in the discussion and analysis of critical health-care issues and will promote their collaboration in the formulation of recommendations, demands, and proposals.

Participants also suggested that the MHC should meet once a month with the public of each region within the municipality, to get close to the community, and gain a better understanding of their needs. They believe that this would lead to greater public participation and improved representativeness of the Council.

I would like to see the MHC go beyond the monthly meetings, and go into the areas of the city. (U3)

Previous studies have highlighted the need for the MHC to meet each region of the municipality to connect to the people and to create an open space for discussion, as a necessary step in the process of democratization. Mutual social bonds and environments for dialogue are necessary to regain the political initiative of social groups, which leads to the awareness of rights and to taking action (Gastal \& Gutfreind, 2007).

In addition, Cruz et al. (2012) report connecting with the community, through meetings, as an essential element in the process of public participation. This strategy gives the public an opportunity to discuss and provide feedback on health-care services. 
The Brazilian literature identifies the problem of representativeness in the MHC as one of the most frequent and difficult problems to solve (Labra, 2009; Rezende \& Moreira, 2016; Wendhausen \& Caponi, 2002). The study on the Local Health Councils in the city of São Paulo, carried out by Coelho (2007), is interesting in that it identified the following three key factors, acting simultaneously, that seem to improve the representativeness and the democratic legitimacy of the participatory spaces: the commitment of public officers to the project of citizens' participation, the presence of a mobilized civil society, and some knowledge about how to organize participatory institutions.

A proposal was made to improve representativeness by modifying the internal regulations of the Council, preventing re-election to the same position, and recommending the rotation of the councillors. However, although this strategy could help to increase democracy within the council and provide access to different representatives of the community, it could also hinder the process of qualification of councillors, creating opportunities for representatives of wealthier segments of the population to exercise influence in decision making (Sipioni \& Silva, 2015). Thus, the issue is not restricted to the term of office of the councillors, but rather is primarily concerned with how the councillor is prepared to perform his/her duties. In this preparation, it is also important to consider the councillor's prior experiences in other participation mechanisms, such as community associations, which will certainly influence their performance at the MHC.

I am against anyone staying more than four years in a position and being re-elected, (...) People start thinking about their own interests. (U5)

I think the MHC works well, but it has representation problems, the people are always the same. (P1)

The state responds more favorably to those groups that are more organized and familiar with public bureaucracy, revealing that this situation is part of a historical context (Valla, 1994). In this way, the institutionalization of participation mechanisms can become an instrument for maintaining power relations in society, since the more structured are consistently favored. There is, therefore, a risk that participation will favor those who are better educated and wealthier (De Freitas \& Martin, 2015), thereby reinforcing existing patterns of social exclusion (Montesanti, Abelson, Lavis, \& Dunn, 2016; Serapioni, 2014). This situation has been described by Fredriksson and Tritter (2017, p. 103) as a paradox, in which "increasing opportunities of participation may increase the overrepresentation of the already well represented."

\section{The Council and Its Influence on Local Health-Care Policies}

The approximately 5,500 health councils involving nearly 80,000 citizens represent an unprecedented phenomenon in a country that, just over 20 years ago, denied any form of transparency in public management (Cortes \& Gugliano, 2010). 
Despite making progress, public participation, like the Brazilian health system itself, is still developing. Social control exercised by the MHC follows a similar pattern: there are still weaknesses and flaws to overcome, for example: not having their demands always considered by decision makers (Escorel \& Moreira, 2009) and the limited impact of the recommendations made by the MHC on the restructuring of services (Coelho, 2011; Van Stralen et al., 2006).

According to the international literature, participation implies the ability to influence the decision-making process. Several studies (Fredriksson \& Tritter, 2017; Serapioni, 2014) emphasize that the voice of the representatives of the citizens has limited effect on the resolutions approved by the health-care authorities. For Morrison and Dearden (2013, p. 179), the role of public participation is "frequently tokenistic" and often unable to influence the outcomes.

The present case study also reported complaints from participants about their limited influence on the MHC.

The public makes recommendations that our officials, managers, do not consider. (U1)

I think more attention should be paid to us. (U2)

Despite the difficulties experienced, the participants observed progress in the health-care services of the city and attributed these achievements to the openness of the MHC, the dialogue and collaboration with the chairperson of the Council, and the organization and tradition of engagement of community associations that act in the neighborhoods of the city. They cited examples of achievements made with the help of the MHC, such as: progress in "HIV/AIDS programs" (U3); "prioritization of basic PSF (Family Healthcare Program) assistance" (P1); enhancement of the "Leva e Traz da Saúde" project (P2); and "establishing Healing Homes" (G1). Among the activities carried out that had a positive impact on the internal and external dynamics of the Council, the interviewees also mentioned the ending of internal by-laws and the creation of decentralized planning workshops.

The councillors' positive assessment of the $\mathrm{MHC}^{\prime}$ s progress and levels of influence on local health policies can be analyzed from the results conducted by Avritzer (2009) in the Northeast region. In Avritzer's research-conducted in the states of Bahia, Ceará, and Pernambuco-he relates the success of the participatory arrangements with the level of development of health associations and the presence of good practices within the MHC. Avritzer (2009) cites practices such as the existence of technical commissions, the presence of equality among members, election of representatives of civil society in plenary, procedures on how to choose the chairperson, and how the council discussion agenda is elaborated.

Some of these elements are present in the MHC of the present study, in which there is, according to the data from this study, a certain tradition of partnerships and social involvement. At the same time, the MHC has developed an institutional 
framework that facilitates the promotion of equality among members, the operation of technical commissions, and the possibility of choosing a representative of the users as chairperson of the council.

\section{Final Considerations}

The results revealed that the MHC of Riberão Preto in São Paulo is building social participation through a process that is marked by both advances and limitations. The difficulties faced internally relate primarily to problems with the physical infrastructure and organizational logistics of the MHC, as well as relational issues between Council members, with their varied roles and levels of knowledge. In the present case study, some elements that characterize the ideal deliberative participation as recommended by deliberative democracy theorists were missing, such as the prior provision of information on topics on the agenda in accessible language so that everyone can debate, defend their positions, and reach consensus.

The representation of the councillors proved to be deficient, corroborating the results of other studies (national and international) that indicate representation as a critical problem of participation. In this regard, communication between representatives and the people they represent is a key area to be developed for improved participation and levels of representation. For example, concerning users, the transfer of information to the community is still informal, and no continuous and formalized relationship exists between users and the sector the councillor represents.

The relevant contribution of the current research is that, despite a certain lack of representativeness, it is possible to perceive active engagement and commitment of the users in the MHC meetings. This result differs from other studies that indicate low participation by the users. In this regard, the research found that the users' experiences and the developments highlighted in the research should be valued, since they represent a crucial step in the construction of the council as a space for the different sectors of society to raise issues and express their expectations around health-care actions and policies.

\section{Limitations}

This was a study case to analyze MHC members' perceptions of citizens' participation in the council. The small number interviewed, only 35 percent of the members, is one of the main limitations of this study. As such, the findings may not be generalizable. Future studies might be conducted involving more councillors. In addition, future research on the quality and effectiveness of participation might be expanded to include other MHCs.

Carla A. A. Ventura, PhD, is an associate professor at the University of São Paulo and Director of the PAHO/WHO Collaborating Centre for Nursing Research Development, Brazil. Her research focuses on mental health and 
human rights, global health, social participation and control, and the right to development.

Mauro Serapioni, PhD, is a researcher at the Centre for Social Studies, University of Coimbra, Portugal. His research focuses on social participation, health evaluation, investigation methods and techniques, social inequities, compared health systems.

Marcela Jussara Miwa is a $\mathrm{PhD}$. Her research focuses on complementary therapies, traditional medicines, right to health, social participation in health, narratives and life history.

Márjore Serena Jorge is an MD, and has completed her master's thesis on social participation in health.

\section{Notes}

This work was supported by the Fundação de Amparo à Pesquisa.

Conflicts of Interest: None declared.

Corresponding author: Carla Aparecida Arena Ventura, caaventu@eerp.usp.br

1. G, P, and U represent the Portuguese terms: gestores (managers), prestadores de serviços (service providers), and usuários (users). For the sake of continuity across all the data, the Portuguese designations for participants will be used.

\section{References}

Abelson, Julia, Pierre-Gerlier Forest, John Eyles, Patricia Smith, Elisabeth Martin, and Francois-Pierre Gauvin. 2003. "Deliberations About Deliberative Methods: Issues in the Design and Evaluation of Public Participation Process." Social Science E Medicine 57 (2): 239-51. https://doi.org/10.1016/ S0277-9536(02)00343-X

Alencar, Heloisa Helena R. 2012. “Educação Permanente No Âmbito Do Controle Social No SUS: A Experiência De Porto Alegre-RS." Saúde e Sociedade 21 (Suppl 1): 223-33. https://doi.org/10.1590/ S0104-12902012000500019

Avritzer, Leonardo. 2009. “Associativismo E Participação Na Saúde: Uma Análise Da Questão Na Região Nordeste Do Brasil." In Participação, Democracia E Saúde, ed. Sonia Fleury, and Lenaura de Vasconcelos Costa Lobato. Rio de Janeiro: CEBES, 151-74.

Barnes, Marian, Chris Skelcher, Hanne Beirens, Robert Dalziel, Stephen Jeffares, and Lynne Wilson. 2008. Designing Citizen-Centered Governance. Birmingham, UK: Joseph Rowntree Foundation.

Batista, Elizabeth C., and Elza M. Melo. 2011. “A Participação Popular em Ipatinga (MG, Brasil): Conquistas e Desafios do Setor de Saúde." Ciência E Saúde Coletiva 16 (1): 337-47. https://doi.org/10.1590/S1413-81232011000100036

Bezerra, Cynthia Kelly F. 2009. “Conselho Municipal De Saúde De Pedras Do Fogo-PB: Um Estudo Sobre Participação." Revista de Administração em Saúde 11 (42): 30-42.

Bispo Júnior, José Patrício, and Sílvia Gerschman. 2015. “Legitimidade Da Representação Em Instâncias De Participação Social: O Caso Do Conselho Estadual De Saúde Da Bahia, Brasil." Cadernos De Saúde Pública 31 (1): 183-93. https://doi.org/10.1590/0102-311×00086214

Bovenkamp, Hester M., Margo J. Trappenburg, and Kor J. Grit. 2009. "Patient Participation in Collective Healthcare Decision Making: The Dutch Model." Health Expectations 13 (1): $73-85$. https://doi.org/10.1111/j.1369-7625.2009.00567.x

Brasil. Tribunal de Contas da União. 4a Secretaria de Controle Externo. 2010. Orientações para Conselheiros de Saúde [Online]. https://central3.to.gov.br/arquivo/314161/. Accessed April 24th, 2017. 
Callon, Michel, Pierre Lascoumes, and Yannick Barthe. 2001. Agir dans un Monde Incertain: Essai sur la Démocratie Technique. Paris: Seuil.

Charles, Cathy, and Suzanne De Maio. 1993. "Lay Participation in Health Care Decision Making: A Conceptual Framework." Health Politics, Policy and Law 18 (4): 881-904.

Coelho, V. Schattan 2007. "Brazilian Health Councils: Including the Excluded?" In Spaces for Change? The Politics of Citizen Participation in New Democratic Arena, ed. John Gaventa. London: ZED Books.

_ 2011. "Uma Metodologia Para a Análise Comparativa De Processos Participativos: Pluralidade, Deliberação, Redes E Política De Saúde." In Efetividade Das Instituições Participativas No Brasil: Estratégias De Avaliação. Brasília: IPEA.

Conklin, Annalijn, Zoë Morris, and Ellen Nolte. 2015. "What Is the Evidence Base for Public Involvement in Health-Care Policy? Results of a Systematic Scoping Review." Health Expectations 18 (2): 153-65. https://doi.org/10.1111/hex.12038

Cooper, Liz. 1995. Voices Off: Tackling the Democratic Deficit in Health. London: Institute for Public Policy Research.

Cornwall, Andrea. 2007. "Democratizing the Governance of Health Services: The Case of Cabo de Santo Agostino, Brasil." In Spaces for Change? The Politics of Citizen Participation in New Democratic Arena. "Brazilian Health Councils: Including the Excluded?" London: ZED Books.

Cornwall, Andrea, and Alex Shankland. 2008. “Engaging Citizens: Lessons From Building Brazil's National Health System." Social Science \& Medicine 66 (10): 2173-84. https://doi.org/10.1016/j. socscimed.2008.01.038

Cortes, Vargas, and Alfredo Gugliano. 2010. “Entre Neocorporativistas E Deliberativos: Uma Interpretação Sobre Os Paradigmas De Análise Dos Fóruns Participativos No Brasil." Sociologias 12 (24): 44-75. https:/ / doi.org/ 10.1590/S1517-45222010000200004

Cotta, Rosângela M., Poliana C. Martins, Rodrigo S. Batista, Sylvia C. C. Franceschinni, Silvia E. Priore, and Fabio F. Mendes. 2011. “O Controle Social Em Cena: Refletindo Sobre a Participação Popular No Contexto Dos Conselhos De Saúde." Physis: Revista De Saúde Coletiva 21 (3): 1121-37. https: / / doi.org/10.1590/S0103-73312011000300019

Cristo, Solange A. 2012. “Controle Social Em Saúde: O Caso Do Pará." Serviço Social E Sociedade (109): 93-111. https://doi.org/10.1590/S0101-66282012000100006

Cruz, Pedro J. C., Samara C. R. Vieira, Nayara M. Massa, Thaise A. M. Araujo, and Ana Cláudia C. Vasconcelos. 2012. “Desafios Para a Participação Popular Em Saúde: Reflexões a Partir Da Educação Popular Na Construção De Conselho Local De Saúde." Saúde E Sociedade 21 (4): 1087-100. https://doi.org/10.1590/S0104-12902012000400025

De Freitas, Cláudia, and Graham Martin. 2015. "Inclusive Public Participation in Health: Policy, Practice and Theoretical Contributions to Promote the Involvement of Marginalised Groups in Healthcare." Social Science \& Medicine (135): 31-39. https://doi.org/10.1016/j. socscimed.2015.04.019

Dryzek, John. 2009. “Democratization as Deliberative Capacity Building." Comparative Political Studies 42 (11): 1379-409. https://doi.org/10.1177/0010414009332129

Duarte, Elisfabio B., and Maria de Fátima A. Machado. 2012. “O Exercício Do Controle Social No Âmbito Do Conselho Municipal De Saúde De Canindé. CE." Saúde E Sociedade 21 (Suppl 1): 126-37. https://doi.org/10.1590/S0104-12902012000500011

Escorel, Sarah, and Marcelo Moreira. 2009. “Desafios da Participação Social em Saúde na Nova Agenda da Reforma Sanitária: Democracia Deliberativa e Efetividade." In Participação, Democracia e Saúde, ed. Sonia Fleury, and Lenaura de Vasconcelos Costa Lobato. Rio de Janeiro: CEBES, 229-47.

Fredriksson, Mio, and Jonathan Tritter. 2017. "Disentangling Patient and Public Involvement in Healthcare Decisions: Why the Difference Matters." Sociology of Health E Illness 39 (1): 95-111. https://doi.org/10.1111/1467-9566.12483

Gastal, Cláudio Luis C., and Celso Gutfreind. 2007. “Um Estudo Comparativo De Dois Serviços De Saúde Mental: Relações Entre Participação Popular E Representações Sociais Relacionadas Ao Direito à Saúde." Cadernos De Saúde Pública 23 (8): 1835-44. https://doi.org/10.1590/S0102$311 \times 2007000800010$ 
Grönlund, Kimmo, André Bächtiger, and Maija Setälä. 2014. Deliberative Mini-Publics. Involving Citizens in the Democratic Process. Colchester, UK: European Consortium for Political Research (ECPR).

Gooberman-Hill, Rachel, Jeremy Horwood, and Michael Calnan. 2008. "Citizens' Juries in Planning Research Priorities: Process, Engagement and Outcome." Health Expectations 11 (3): 272-81. https://doi.org/10.1111/j.1369-7625.2008.00502.x

Labra, Maria Eliana 2009. "Política Nacional De Participação Na Saúde: Entre a Utopia Democrática Do Controle Social E a Práxis Predatória Do Clientelismo Empresarial." In Participação, Democracia e Saúde, ed. Sonia Fleury and Lenaura de Vasconcelos Costa Lobato. Rio de Janeiro: CEBES, 176-203.

Lehoux, Pascalel, Genevieve Daudelin, Olivier Demers-Payette, and Antoine Boivin. 2009. "Fostering Deliberations About Health Innovation: What Do We Want to Know From Publics?" Social Science $\mathcal{E}$ Medicine 68 (11): 2002-09. https://doi.org/ 10.1016/j.socscimed.2009.03.017

Li, Kathy K., Julia Abelson, Mita Giacomini, and Damien Contandriopoulos. 2015. “Conceptualizing the Use of Public Involvement in Health Policy Decision-Making." Social Science E Medicine (138): 14-21. https://doi.org/10.1016/j.socscimed.2015.05.023

Maxwell, Judith, Steven Rosell, and Pierre-Gerlier Forest. 2003. “Giving Citizens a Voice in Healthcare Policy in Canada." British Medical Journal 326 (7397): 1031-33. https:/ /doi.org/10.1136/bmj.326.7397.1031

Mitton, Craig, Neale Smith, Stuart Peacock, Brian Evoy, and Julia Abelson 2009. "Public Participation in Health Care Priority Setting: A Scoping Review." Health Policy 91 (3): 219-28. https://doi.org/10.1016/j.healthpol.2009.01.005

Montesanti, Stephanie R., Julia Abelson, John N. Lavis, and James R. Dunn. 2016. "Enabling the Participation of Marginalized Populations: Case Studies From a Health Service Organization in Ontario, Canada." Health Promotion International 1 (14): 636-49. https://doi.org/10.1093/heapro/dav118

Morrison, Cecily, and Andy Dearden. 2013. “Beyond Tokenistic Participation: Using Representational Artefacts to Enable Meaningful Public Participation in Health Service Design." Health Policy 112 (3): 179-86. https://doi.org/10.1016/j.healthpol.2013.05.008

Parkin, Lianne, and Charlotte Paul. 2011. “Public Good, Personal Privacy: A Citizens' Deliberation About Using Medical Information for Pharmacoepidemiological Research." Journal of Epidemiology and Community Health 65 (2): 150-56. https:/ / doi.org/10.1136/jech.2009.097436

Patton, Michael Q. 1999. "Enhancing the Quality and Credibility of Qualitative Analysis." Health Services Research 34 (5): 1189-208.

Quivy, Raymond, and Luc van Campenhoudt. 1998. Manual de Investigación en Ciencias Sociales. México City: Limusa Noriega.

Rezende, Raphael B., and Marcelo R. Moreira. 2016. “Relações Entre Representação E Participação No Conselho Municipal De Saúde Do Rio De Janeiro: Segmento Dos Usuários, 2013-2014." Ciência E Saúde Coletiva 21 (5): 1409-20. https: / / doi.org/10.1590/1413-81232015215.00352016

Rolim, Leonardo B., Rachel S. Cruz, and Karla A. Sampaio. 2013. "Participação Popular E O Controle Social Como Diretriz Do SUS: Uma Revisão Narrativa." Saúde Em Debate 37 (96): 139-47. https://doi.org/10.1590/S0103-11042013000100016

Rojatz, Daniela, and Rudolf Forster. 2017. "Self-Help Organisations as Patient Representatives in Health Care and Policy Decision-Making." Health Policy 121 (1): 1047-52. https://doi.org/ 10.1016/j.healthpol.2017.08.012

Santos, Boaventura S. 2002. Democratizar a Democracia. Os Caminhos da Democracia Participativa. Rio de Janeiro: Civilização Brasileira.

Scutchfield, Douglas F, Laura Hall, and Carol L. Ireson. 2006. “The Public and Public Health Organizations: Issues for Community Engagement in Public Health." Health Policy 77 (1): $76-85$. https://doi.org/10.1016/j.healthpol.2005.07.021

Serapioni, Mauro. 2014. “Os Desafios Da Participação E Da Cidadania Nos Sistemas De Saúde." Ciência E Saúde Coletiva 19 (12): 4824-37. https:/ / doi.org/ 10.1590/1413-812320141912.02292013 
Serapioni, Mauro, and Nancy Duxbury. 2012. "Citizens Participation in the Italian Health-Care System: The Experience of the Mixed Advisory Committees." Health Expectations 17 (4): 488-99. https://doi.org/10.1111/j.1369-7625.2012.00775.x

Silva, Elaine C., and Maria Cecília F. Pelicioni. 2013. "Participação Social E Promoção Da Saúde: Estudo De Caso Na Região De Paranapiacaba E Parque Andreense." Ciência E Saúde Coletiva 18 (2): 563-72. https://doi.org/10.1590/S1413-81232013000200028

Sipioni, Marcelo E., and Marta Z. Silva. 2015. “Democracia E Saúde: A Prestação De Contas Como Legitimadora Da Representação No Conselho Municipal De Saúde De Vitória (ES)." Saúde Em Debate 39 (104): 197-209. https:/ /doi.org/10.1590/0103-110420151040419

Soratto, Jacks, and Regina R. Witt. 2013. “Participação E Controle Social: Percepção Dos Trabalhadores Da Saúde Da Família." Texto \& Contexto, 22 (1): 89-96. https://doi.org/10.1590/S0104-07072013000100011

Tritter, Jonathan Q., and Alison McCallum. 2006. “The Snakes and Ladders of User Involvement: Moving Beyond Arnstein." Health Policy 76 (2): 156-58. https:/ / doi.org/ 10.1016/j.healthpol.2005.05.008

Valla, Victor V. 1994. Educação, Saúde e Cidadania. Petrópolis, Brazil: Vozes.

Van Stralen, Cornelis J., Ângela M. D. Lima, Delcio da Fonseca Sobrinho, Leonor E. S. Saraiva, Terezinha B. S. van Stralen, and Soraya A. Belisário. 2006. "Conselhos De Saúde: Efetividade Do Controle Social Em Municípios De Goiás E Mato Grosso Do Sul." Ciencia E Saúde Coletiva 11 (3): 621-32. https://doi.org/10.1590/S1413-81232006000300011

Ventura, Carla Ap. A., Débora F. Mello, Raquel D. Andrade, and Isabel A. C. Mendes. 2012. "Aliança Da Enfermagem Com O Usuário Na Defesa Do SUS." Revista Brasileira De Enfermagem 65 (6): 893-8. https://doi.org/10.1590/S0034-71672012000600002

Vieira, Mónica B., and Filipe C. Silva. 2013. "Democracia Deliberativa Hoje: Desafios E Perspectivas." Revista Brasileira De Ciência Politica (10): 151-94. https://doi.org/ 10.1590/S0103-33522013000100005

Wendhausen, Águeda, and Sandra Caponi. 2002. “O Diálogo E a Participação Em Um Conselho De Saúde Em Santa Catarina, Brasil." Cadernos De Saúde Pública 18 (6): 1621-28. https://doi.org/ $10.1590 /$ S0102-311 ×2002000600016

Yin, Robert. 1994. Case Study Research. Design and Methods. 4th ed. Thousand Oaks, CA: Sage Publications. 